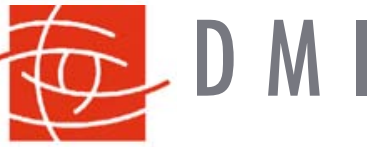

DESIGN MANAGEMENT INSTITUTE

\title{
ARTICLE REPRINT
}

Design

Management

Review

\section{The Four Powers of Design: A Value Model in Design} Management

Brigitte Borja de Mozota, Professor, Université Paris $X$

Reprint \#06172BOR44

This article was first published in Design Management Review Vol. 17 No. 2

Adding Value Through Design

Copyright $\odot$ Spring 2006 by the Design Management Institutess. All rights reserved. No part of this publication may be reproduced in any form without written permission. To place an order or receive photocopy permission, contact DMI via phone at (617) 338-6380, Fax (617) 338-6570, or E-mail: dmistaff@dmi.org. The Design Management Institute, DMI, and the design mark are service marks of the Design Management Institute.

www.dmi.org 


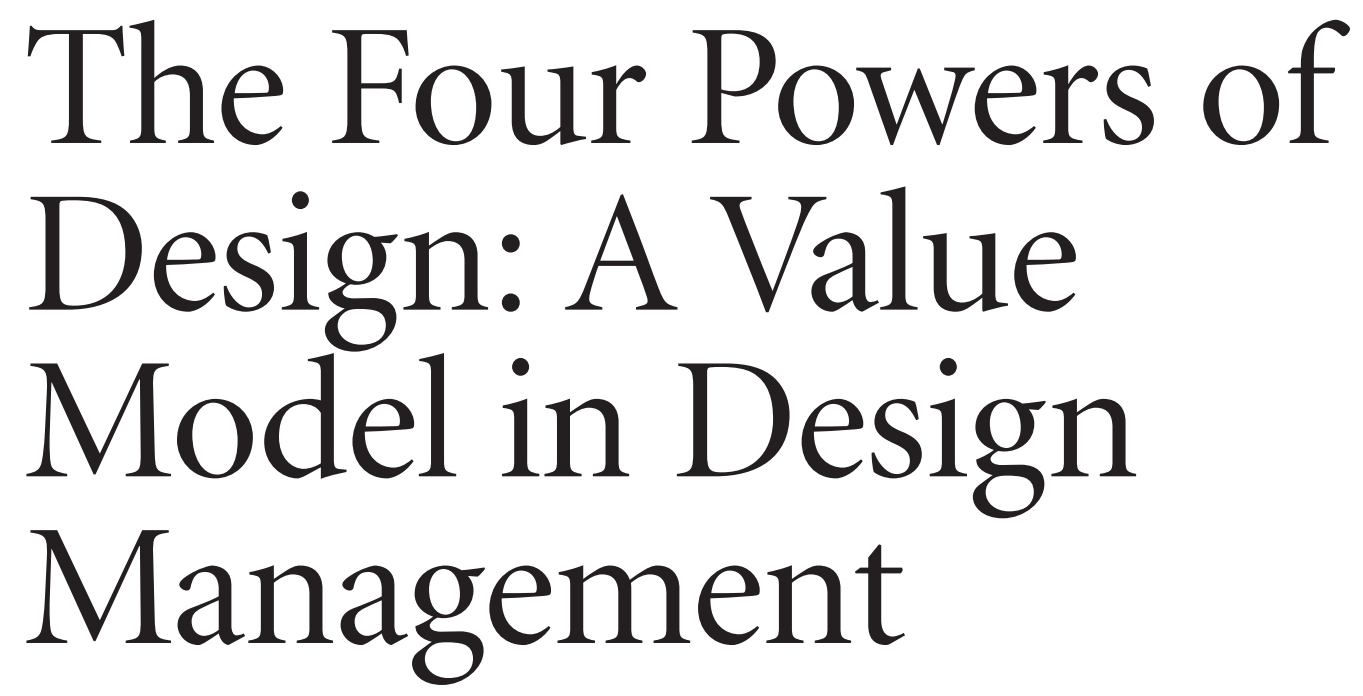

by Brigitte Borja de Mozota

7 his analysis proposes a framework to bridge the gap between the world of from Steelcase, Decathlon, and other companies, Brigitte Borja de Mozota parallels design's ability to differentiate, integrate, transform, and contribute to the enterprise and bottom-line results with a corporate focus on markets, processes, talent, and finances.

In summer 2005, BusinessWeek published a 20-page special report on building innovative companies." The report celebrates the emergence of a "creativity economy" in which managers are starting to discover "design strategy." In addition, Innovation 2005, Boston Consulting Group's second annual survey of 940 senior executives, ranked two icons of the design community, Apple and Sony, in the top five of the world's twenty most innovative companies. Taking their cue from the creativity economy, universities and business schools from Toronto to Paris are taking up new collaborations with design schools.

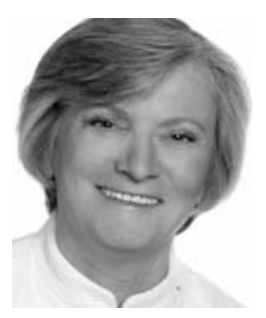

Brigitte Borja de Mozota, Professor, Management Science, Université Paris $X$, ESSEC, France,

DMI Life Fellow
Although the trend in favor of design can be seen as a way to promote design as a qualified partner for innovation and management, it's a trend that tends to forget about design management-a simplistic view that risks relegating design skills to the vague realm of creativity and the development of "wow" products, conveying the idea that merely collaborating with designers is enough.

Instead, business managers should know about design management's power to create value in companies,

1. "Get Creative: How to Build Innovative Companies,” BusinessWeek, August 1, 2005. 
which has been proven through research and can also be demonstrated through management concepts such as Michael Porter's value chain. In this article, I hope to describe to design professionals a research-based value model for design management and to convey to them how this model can be implemented using Robert Kaplan's and David Norton's Balanced Score Card (BSC) decision tool ${ }^{2}$ - a tool that should be familiar to all kinds of business managers.

\section{The Four Powers of Design}

My research on design-oriented European SMEs became the basis of a value model for design as differentiator, integrator, and transformer. ${ }^{3}$ It also introduced the concept of the four powers of design, in the context of management science. These four powers are:

1. Design as differentiator: Design as a source of competitive advantage on the market through brand equity, customer loyalty, price premium, or customer orientation

2. Design as integrator: Design as a resource that improves new product development processes (time to market, building consensus in teams using visualization skills); design as a process that favors a modular and platform architecture of product lines, user-oriented innovation models, and fuzzy-front-end project management

3. Design as transformer: Design as a resource for creating new business opportunities; for improving the company's ability to cope with change; or (in the case of advanced design) as an expertise to better interpret the company and the marketplace

\section{Design as good business: Design as a} source of increased sales and better margins, more brand value, greater market share, better return on investment (ROI); design as a resource for society at large (inclusive design, sustainable design)

2. For more information on the Balanced Score Card methodology, see R. Kaplan and D. Norton, "Linking the Balanced Scorecard to Strategy," California Management Review, vol. 39 (1996), no. 1.

3. Brigitte Borja de Mozota, "Design and Competitive Edge: A Model for Design Management Excellence in European SMEs," DMI Academic Review, 2 (2002).

\begin{tabular}{|c|c|c|c|}
\hline $\begin{array}{l}\text { DESIGN } \\
\text { AS STRATEGY }\end{array}$ & $\begin{array}{l}\text { Controling design } \\
\text { ROI \& business } \\
\text { performance and } \\
\text { brand value. }\end{array}$ & $\begin{array}{l}\text { Design leadership. } \\
\text { Coherence of the } \\
\text { design system and } \\
\text { driving the future } \\
\text { "advanced design." }\end{array}$ & $\begin{array}{l}\text { Design as resource } \\
\text { for the challenges of } \\
\text { contemporary } \\
\text { managers-Socially } \\
\text { responsible } \\
\text { enterprise. }\end{array}$ \\
\hline $\begin{array}{l}\text { DESIGN } \\
\text { AS PROCESS }\end{array}$ & $\begin{array}{l}\text { Design research } \\
\text { methods-ethno } \\
\text { design, etc. } \\
\text { DM as managing the } \\
\text { design function. }\end{array}$ & $\begin{array}{l}\text { Integrating design } \\
\text { in other processes: } \\
\text { brand, innovation, } \\
\text { TQM. } \\
\text { DM as improving the } \\
\text { performance of } \\
\text { processes. }\end{array}$ & $\begin{array}{l}\text { Integrating design in } \\
\text { management decision } \\
\text { processes. } \\
\text { DM as inventing the } \\
\text { future and "sense } \\
\text { building" in a } \\
\text { changing } \\
\text { environment. } \\
\text { DM for the quality } \\
\text { of staff. }\end{array}$ \\
\hline $\begin{array}{l}\text { DESIGN } \\
\text { AS STYLING }\end{array}$ & $\begin{array}{l}\text { Integrating design in } \\
\text { marketing, R\&D, } \\
\text { corporate } \\
\text { communications. } \\
\text { DM as managing a } \\
\text { design project. }\end{array}$ & & \\
\hline & $\begin{array}{l}\text { MANAGEMENT AS } \\
\text { COMMAND\& CONTROL }\end{array}$ & $\begin{array}{l}\text { MANAGEMENT AS } \\
\text { ART OF COLLECTIVE } \\
\text { ACTION }\end{array}$ & $\begin{array}{l}\text { MANAGEMENT AS } \\
\text { MANAGING CHANGE }\end{array}$ \\
\hline
\end{tabular}

Figure 1. Design management is defined by what you think of design (vertical axis: the "learning ladder" of design), and by what you think of management (horizontal axis). 


\section{Design in the Value Management Model}

Design is thus fairly easily integrated into the value management model. So what is the problem? Why are designers still suffering from lack of recognition and support from managers? Our insight is that there are two missing links:

1. Designers' lack of knowledge of management concepts and of management as a science

2. Designers' difficulty in implementing a value model in their everyday practices

In addition, the scope of design management has changed. This is the result of business' changed understanding of the place of design in an organization, as well as of designers' changed understanding of the scope of business management (Figure 1 on page 45). In this way, design management spreads from project design management to strategic design management in a dynamic process.

Before the value of design to a firm can be measured, it is crucial to measure that firm's efficiency in relation to the efficiency of its industry. Each market sector has its specific growth potential and its norms in terms of profitability. In other words, the first question to ask a design manager is whether the superior product or service achieved through design brings profits superior to the mean in the industry.

Designers should keep in mind that there are more differences among companies in the same industry than among companies across industries. In every industry, technology, distribution, and marketing tend to be similar. A company competes through inventing a combination of these resources that make its offer unique and its EVA (economic value added) superior. Value in management science happens by achieving a result superior to that of the competition, not just by making a well-designed product. And a superior result is defined as a greater ratio between the profits realized and the capital invested.

Let us assume that your organization has a result that is close to the mean of your industry and that you think design can bring better value to your organization. Or perhaps you want to invent a new business unit that boasts a superior EVA. How do you teach managers and CEOs to be better at their jobs because of the input of design?

You can explain that through design they can develop a competitive advantage that will be valued by the market - truly, an objective of any manager (Figure 2). But how do you build that advantage?

First, consider that competitive advantage can take two forms:

1. Design as differentiator. External, marketbased advantage derived from the designbased differentiation of the company's product or service (design of products, design as perceived value, brand design value, corporate image)

2. Design as coordinator or integrator. Internal competitive advantage that comes from a unique, invisible, and difficult-to-imitate combination of organizational processes and resources (that is, a resource-based view: design as process, design as knowledge, design science, design as resource, advanced design for new business)

Companies in the first camp are really thinking of design in a reputational, or brand, context. Companies in the second camp understand design as a core competency.

Now, consider that EVA comes from two types of value: financial and substantial.

\begin{tabular}{|c|c|c|c|}
\hline \multicolumn{4}{|c|}{ ECONOMIC VALUE ADDED (EVA) } \\
\hline \multicolumn{3}{|c|}{ SUBSTANTIAL VALUE } & FINANCIAL VALUE \\
\hline Customer & Performance & Strategic & \\
\hline Value & Value & Value & \\
\hline \multicolumn{4}{|c|}{$\begin{array}{l}\text { COMPETITIVE ADVANTAGE } \\
\text { (External or Resource Based) }\end{array}$} \\
\hline
\end{tabular}

Figure 2. A competitive advantage brings economic value added if both substantial value and financial value are created. 
Financial value is the value created for the company shareholders, partners, or investorsor even society at large, in the case of companies that practice sustainable development-through finance, investment, or mergers. Designers often forget this financial perspective or think of it only in terms of economic value (sales, margin, costs, market share)_forgetting the stock-market power of shareholders and the political forces of stakeholders and laws.

Substantial value is the value created for the company's suppliers, customers, and employees following two rationality schemes:

1. Competitive rationality: The company portfolio represents a value perceived by the market (value chain, customer relation, competitiveness, future cash).

2. Organizational rationality: The company structure is the base of the value created and shared by all human resources - that is, process improvement, individual creativity, knowledge management, performance of projects.

In summary, there are many paths by which a competitive advantage can be built, and the same variety applies to design-driven value.

\section{Implementing Design as Value Using the Balanced Score Card Tool}

Although they know design brings value, designers and design managers still understand that one cannot manage what is not measured. So measuring the impact of design value is a key success factor for designers who want to successfully implement their design strategyand for design managers who want to present design as a tool for value management.

In other words, designers and design managers make a bigger impression on business managers when they use a value-based model to measure the impact of design. I suggest that designers and design managers use the Balanced
Score Card (BSC) methodology mentioned earlier. For designers, the BSC is also easy to appropriate, because it is vision-based, as well as holistic (Figure 3).

The four perspectives of the BSC model neatly coincide with the four powers of design, or the four design values system: customer perspective (design as differentiator); process perspective (design as coordinator); learning perspective (design as transformer); finance perspective (design as good business).

As I noted earlier, the BSC model is widely known by MBAs and often used by audit and strategy consultants. It is a common language shared and understood by most executives, whether they occupy the CEO's office or work in finance, marketing, procurement, or $\mathrm{R} \& \mathrm{D}$. This model is strategic and long-term-driven, which aligns it well with design thinking and design coherence, also based on long-term thinking. It offers help in asking about the four issues that are key to every design project: that is, client, performance, knowledge management, and finances. It is also simple to apply to any design

How should we appear, through
design, to our customers in order to
achieve our vision?
1. DESIGN AS DIFFERENCE.
DESIGN MANAGEMENT AS
PERCEPTION \& BRAND
Market value
Customer value
Brand
Consumer research

How will we sustain, through design, our ability to change and improve?

3. DESIGN AS VISION. BEYOND "ADVANCED DESIGN" MANAGEMENT

Strategic value Vision

Prospective

Change management

Empowerment

Knowledge learning process

Imagination
To satisfy our stakeholders, how can design help in the business processes we excel in?

2. DESIGN AS PERFORMANCE. DESIGN MANAGEMENT AS " $A$ " AS INNOVATION PROCESS

Innovation

Modular architecture

Time to market

TQM

$R \& D$

Technology

\section{VISION}

To succeed financially, how should design appear to our shareholders?

4. "GOOD DESIGN IS GOOD BUSINESS". THE HISTORIC DM ECONOMIC MODEL Financial \& accounting value $\mathrm{ROI}$

Value for society Stock market value Socially responsible enterprise

Figure 3. It is crucial to explain in any design brief, and to measure in any design project, how design creates value from the four perspectives of the Balanced Score Card model. Source: R. Kaplan and D. Norton, "Linking the Balanced Scorecard to Strategy," California Management Review, vol. 39 (1996), no. 1. 
decision, design policy, or design project.

But more important, the BSC tool is a causeand-effect model, in that each perspective has an impact on the other three. Employee quality, for example, drives customer value and financial value; process improvement affects financial value and customer value, and so on. Just as a designer working on a project is used to thinking holistically, the BSC indicators are meant systemically - improving the quality of product design improves employee satisfaction and creates new knowledge that can generate better production process performance (and vice versa). In the same way, the BSC shows how each design discipline is linked with other design disciplines in a system based on a common, central vision.

The cases starting on page 49 are examples of the implementation of this model in three companies, each of which focuses on a different design discipline: Attoma (information design); Decathlon (product design); and Steelcase (workspace design).

\section{The Balanced Score Card for Running a Design Department or a Consultancy}

Now, how shall we apply the Balanced Score Card to measure the performance of a design consultancy or a design department?

Imagine that you are a design manager or a CEO. What issue faces you both when you come in to work each morning? Company performance. What is design's responsibility in improving this performance? What indicators should you measure on a continuing basis? How could that goal be expressed with the design value model or the four BSC perspectives? Figure 4 offers an example.

For each of the four BSC perspectives, we chose indicators that are easy to measure and easy to link with company performance indicators. Some indicators are used by many functions of the organization; some are specific to the design function. It is important that design managers link their own indicators with the BSC indicators of the company's performance, as well as with design briefs, as a measure of the everyday performance of design staff.

Continued on page 53

\section{THE CUSTOMER VALUE PERSPECTIVE \\ How should we appear, through design, to our customers in order to achieve our vision? \\ Increase market share/\% products or services above mean price. Improve brand image/\% products or services sold under our brands. Improve customer satisfaction/User oriented design: customer satisfaction survey.}

NOISIA

\section{THE LEARNING PERSPECTIVE \\ How does the design department sustain our ability to change and improve?}

Recruit high potential profiles/ Recruitment design.

Competent staff/Improving learning abilities through design.

Motivated and empowered staff/ Working through design on transversal multicultural teams.

\section{THE PERFORMANCE VALUE PERSPECTIVE}

How does the design department improve the process we excel in?

Improving innovation process/more projects conducted per year. Improving production process/fewer defects.

Implementing CRM/

Design in information systems management: fewer complaints.

\section{VISION}

\section{THE FINANCIAL VALUE PERSPECTIVE}

To succeed financially, how should design appear to our shareholders?

Increase turnover/\% sales of new products or services. Improve intangibles/Number of licensed and protected designs. Improve $\mathrm{ROI} / \mathrm{Improve}$ results versus capital invested in design projects. 


\section{Case Study 1. Attoma: The value of information design for business performance}

ompanies are facing increasingly complex environments. Models for managing complexity are needed, and mental visualization models can help. With its horizontal and systemic approach, information design is capable of bringing concrete answers to an intelligent management of complexity. Attoma Design is an information design consultancy based in Paris, founded by Giuseppe Attoma Pepe, board member of the IIID (International Institute for Information Design).

One of Attoma's recent projects was done for RATP, the Paris Métro subway, which was implementing a contactless smart-card system called Navigo. If Navigo was to be successful, it would be vital to humanize the technology. Attoma was asked to design the graphic user interface for the Navigo vending machine. Chief among the methods Attoma used were visualization tools for prototype, test, and reduced time to market. The whole project was a success in sales growth and customer satisfaction, but also in the way it helped to spread the new technology among the general public. It also changed the way in which RATP viewed new product development.

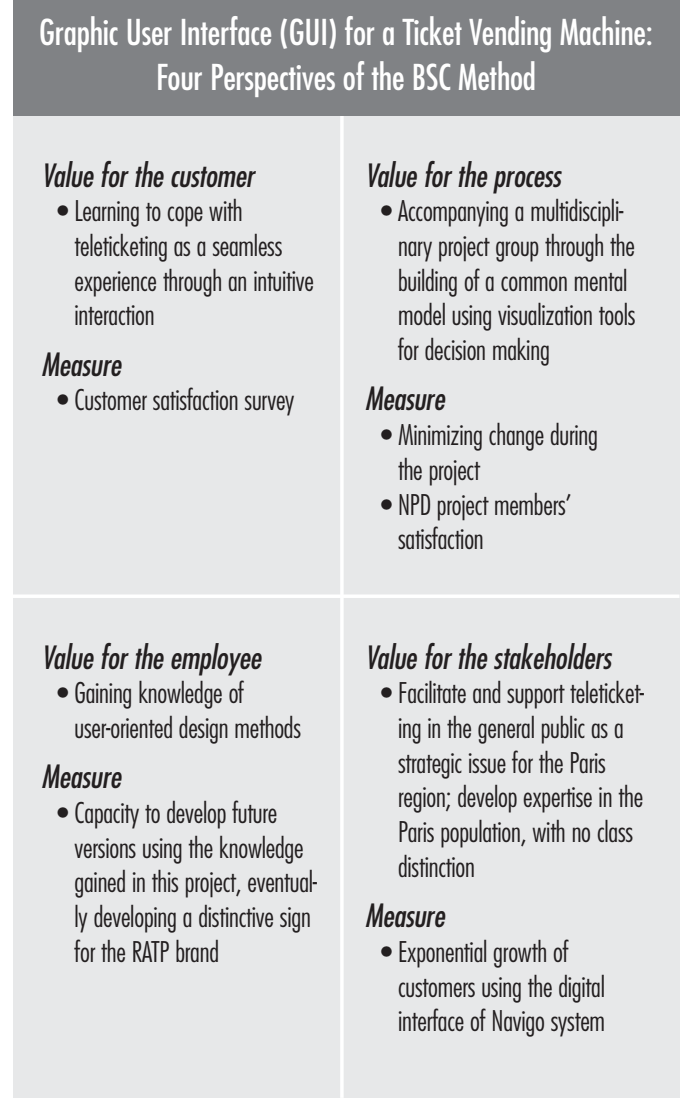

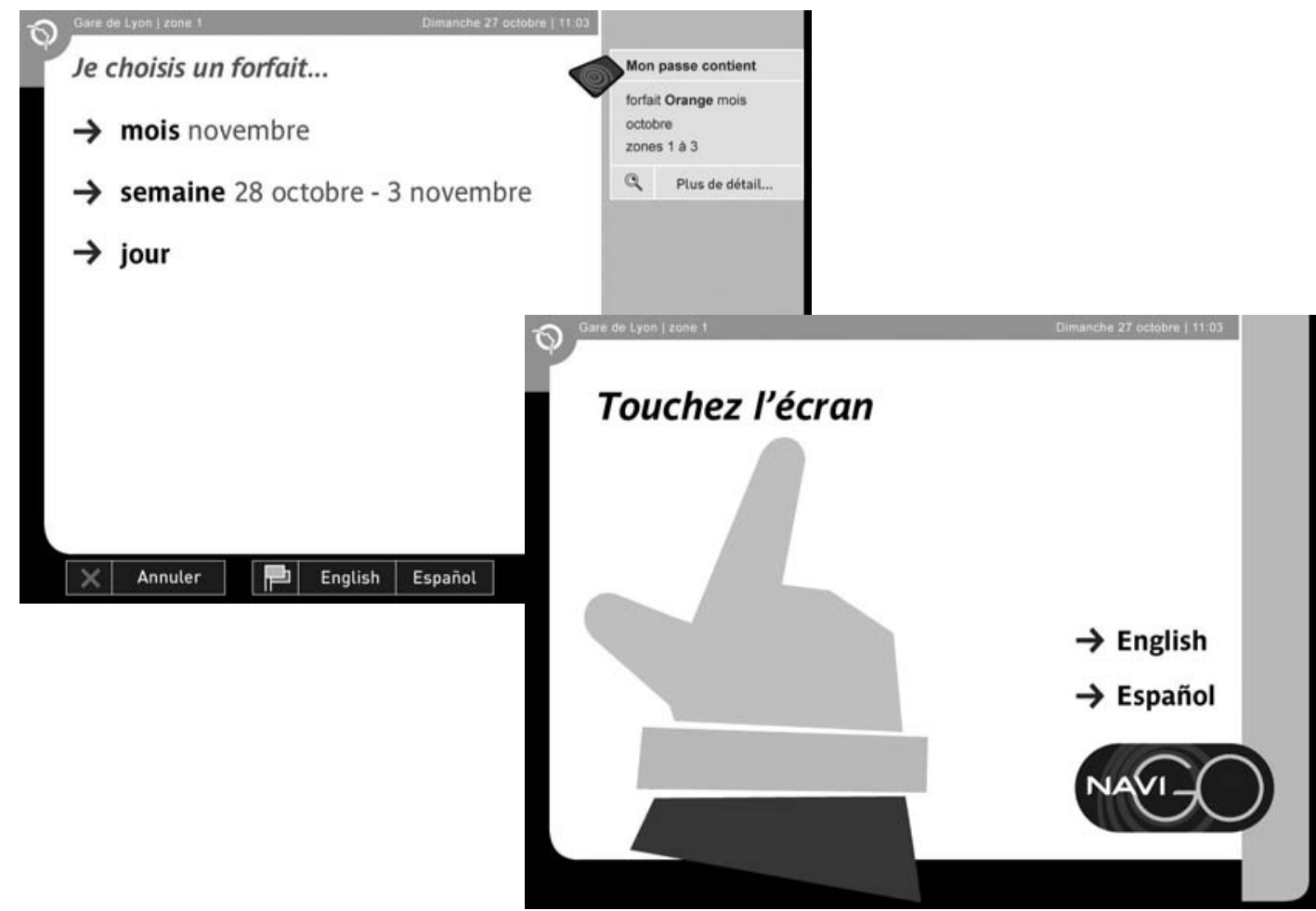




\section{Case Study 2. Decathlon: Designing value into the process}

ince its foundation in 1976, Decathlon has always had a very clear goal: make sport more enjoyable for everyone. In every corner of the globe, this purpose is expressed through two complementary areas of expertise:

1. The design and manufacture of in-house brand sporting goods covering about 65 sports

2. Retailing sporting goods (350 stores worldwide, 22,000 store employees, 35,000 different articles on average per store, and 100 million customers every year)

Decathlon's in-house design team is made up of 90 multi-disciplinary designers sharing the same values: honesty, fraternity, and responsibility, all used toward making the pleasure of sport accessible to all. Many of these designers are practitioners of the sport for which they design.

Nine Decathlon products received International Forum design awards in 2006. One of these was the Tribord Inergy wetsuit for surfing. The Inergy was designed for women. It suits the female morphology and enables women to surf more comfortably and easily. In doing so, it also invites more women to discover the pleasures of surfing. This was a strategic approach for Tribord, and is currently being duplicated in other products.

Case Study 2: continued on next page

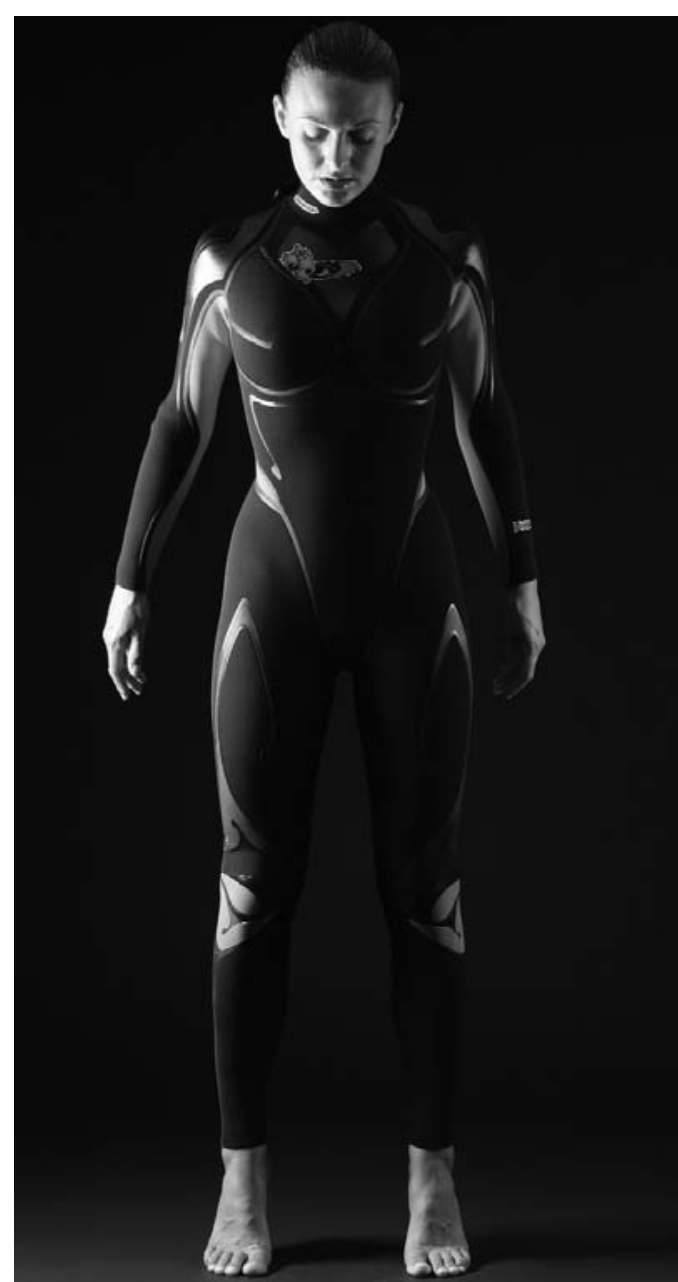

Decathlon's Tribord Inergy surfing wetsuit for women.

The Tribord Inergy Woman's Wetsuit for Surfing: Four Perspectives of the BSC Method

Value for the client

- Surfing is a question of balance. A rigid structure reduces unwanted movements that spoil the balance. The Tribord design actually reduces elasticity in certain directions, making balance much easier.

- The chest area of the Tribord is designed to support each breast independently. This area is similar to a bra, but the two cups are visually integrated in the wetsuit pattern.

\section{Measure}

- Value of Tribord brand

\section{Value for the employee and knowledge management}

- Empowering female employees and improving knowledge management in understanding women's needs and desires. Well appreciated by Emmanuel Joly, five-time Olympic gold medal winner and technical partner for Tribord, as well as by female design team members.

\section{Measure}

- Employee satisfaction, especially among female employees

- New market positioning for all Decathlon brands
Value for the process

- Staying true to a user-oriented innovation process, Tribord as a Decathlon brand has moved its research location close to user practice areas on the French Côte Basque, in Hendaye, where nautical sports are practiced.

- Technology value: Use of silicone on neoprene to control movement; matte areas and shiny areas visually differentiate the functional areas.

\section{Measure}

- Number of new products launched

Value for the shareholders and society

- Design as a resource for shareholder value through the democratization of sports

- Innovation provides exclusivity

Measure

- International Forum design awards improve the company's intangible value. 
Case Study 2: continued

A ard-winning Decathlon product was the Quechua Two-Seconds tent, which radically reduces the time needed to erect a tent. This tent can literally be thrown into the air and will open on its own before it reaches the ground. The idea was to pre-assemble the tent's various elements (room, double roof, hoops) to simplify the camper's life as much as possible. Once the tent is up, the camper has only to put six tent pegs in the ground to secure it. Roomy enough for two, the Two-Seconds Tent is reasonably priced at 49 euros, offering everyone the chance to go off and camp, even if he/she has never put up a tent. At the same time, it is a real tent, with all the technical features of, for instance, a coated double roof with waterproof seams and anti-condensation, or breathable, fabric.

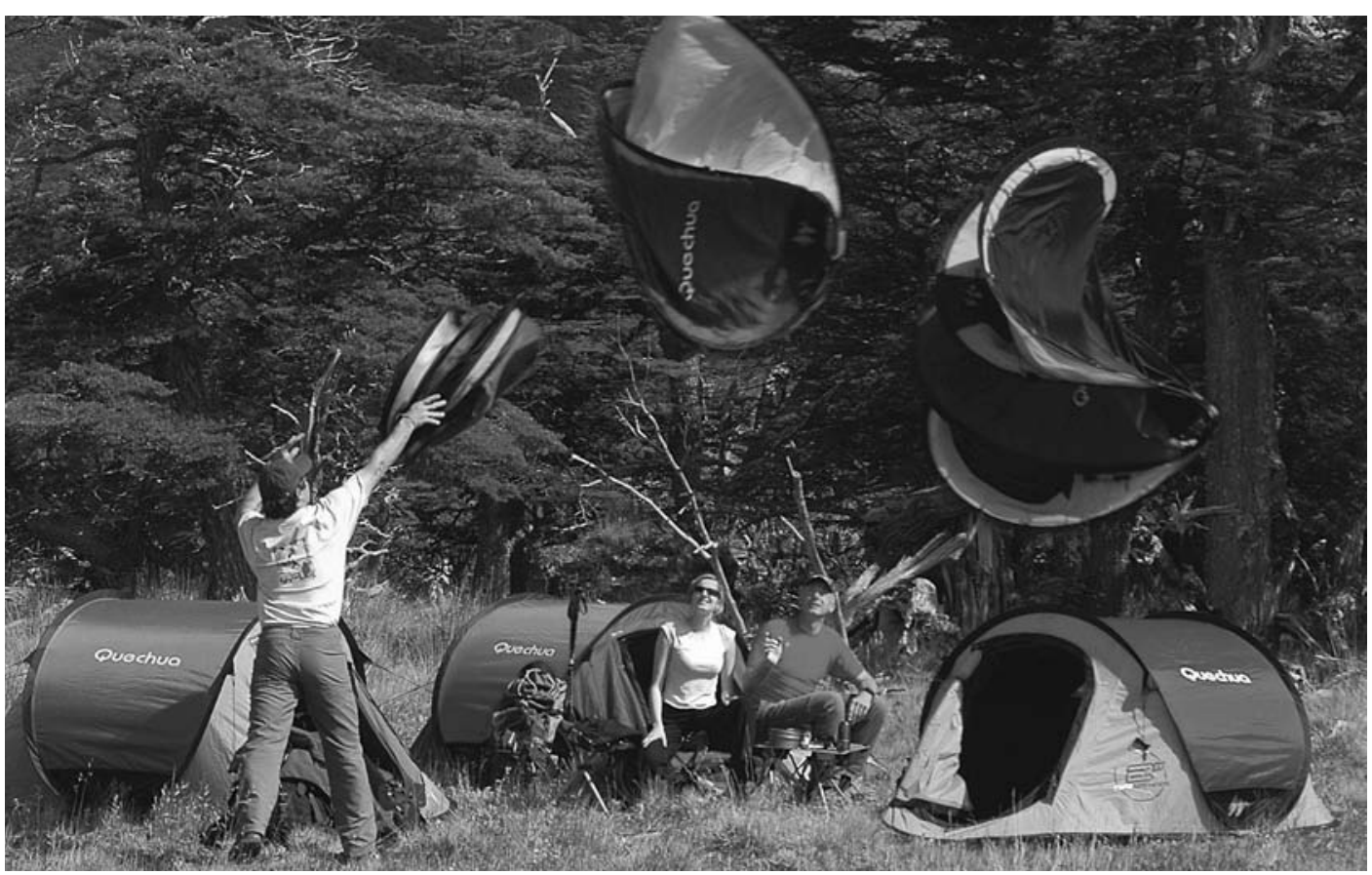

Decathlon's Quechua two-seconds tent literally pitches itself.

\section{Quechua Two-Seconds Tents: Four Perspectives of the BSC Method}

Value for the client

- Spring hoops allow this tent to be thrown into the air and to open up on its own before it reaches the ground

\section{Measure}

- Customer satisfaction in Quechua brand; product used in television campaign

Value for employee and knowledge management

- Development of new innovation processes and progression in the capacity to develop prospective designs

\section{Measure}

- Growth of new concept development in the company (new business opportunity)

\section{Value for the process}

- Better integration of marketing and design upstream in focus groups

- Process innovation: the (patented) process that allows the automatic opening of the tent to include a room and a roof

\section{Measure}

- Fuzzy-front-end NPD process and expertise in design research

- New process for development of future range of tents

\section{Value for shareholders and society}

- Sustainable design (longer lifespan; no packaging —-the cover acts as carrying pack)

- Enabling Quechua to move up on the range of 10-inch little dome tents

\section{Measure}

- 78 percent growth in number of tents sold and 51 percent revenue growth in tent sales in the first year

- Patented model of tent peg

- Design awards in 2006: International Forum and Red Dot design awards, Annual Design Review (USA), Observeur du Design (France) 


\section{Case Study 3. Steelcase: The value of workplace design for business results}

$\Lambda^{s}$ $s$ businesses experience new dimensions of competition, more organizations see how results. Using the workplace as a leverage point, organizations can better facilitate structural realignment; implement new technology; redesign business processes; and reinforce the organization's values, culture, and image.

Measurements related to the workplace have typically focused on cost per workspace, space efficiency, reconfiguration costs, and energy usethe cost side of the cost/benefit equation. The workplace, however, significantly affects an organization's people, processes, and technology. In the business results model shown below, the workplace is one of four key factors that drive business results. Efforts in all four areas must be integrated, balanced, and measured. Using the balanced scorecard model, let us take two examples:

\section{Steelcase Workplace A: Improve worker interaction and workplace flexibility.}

The workspace at this high-tech electronics firm was allocated based on hierarchy, status, and rank. As the firm reengineered and moved to a more fluid, team-based work process, the design of the workplace impeded progress. Team members were located on multiple floors; conference rooms were unavailable on short notice; and moving a person took as long as 12 weeks.

When the firm redesigned the workplace, members of each team were co-located to encourage informal communication. Collaborative space was integrated into the teamwork setting to facilitate interaction. Freestanding furniture within panels cut the time required for personnel moves from 12 weeks to 12 hours. A modular network and lay-in cabling sharply reduced changes to network connections.

Using the four categories of the BSC method (financial value and value for market position, personnel, and process) gives us the result seen in the chart at the right.

Case Study 3: continued on next page

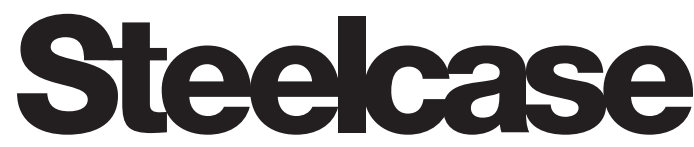

Steelcase logotype

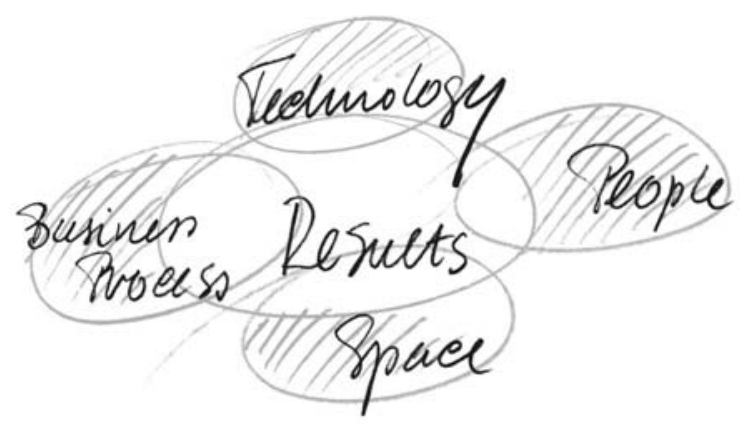

Steelcase business results model

Steelcase Workplace A: Four Perspectives of the BSC Method

\begin{tabular}{|c|c|}
\hline $\begin{array}{l}\text { Value for the market position: } \\
\text { - Increase market share } \\
\text { Measure: } \\
\text { - Percent of market share } \\
\text { contributed by new products }\end{array}$ & $\begin{array}{l}\text { Value for the process: } \\
\text { - Accelerate product } \\
\text { development process } \\
\text { - Implement self-directed } \\
\text { work teams } \\
\text { Measure: } \\
\text { - Time to market (before } \\
\text { and after) }\end{array}$ \\
\hline $\begin{array}{l}\text { Value for personnel and } \\
\text { knowledge management: } \\
\text { - Increase worker interaction } \\
\text { within product development } \\
\text { teams } \\
\text { Measure: } \\
\text { - Workplace flexibility to } \\
\text { support frequently changing } \\
\text { work teams }\end{array}$ & $\begin{array}{l}\text { Financial value: } \\
\text { - Move people and equipment, } \\
\text { not furniture and cables } \\
\text { Measure: } \\
\text { - Time and costs required } \\
\text { for workplace moves, } \\
\text { adds, changes reduced by } \\
72 \text { percent. } \\
\text { - ROl in five years (i.e., in } \\
\text { five years, the company will } \\
\text { have recouped its investment } \\
\text { in design) }\end{array}$ \\
\hline
\end{tabular}

Value for the market position: Value for the process:

- Implement self-directed

- Time to market (before in design)

Financial value: not furniture and cables

Measure:

for workplace moves, adds, changes reduced by ROl in five years (i.e., in five years, the company will 
Case Study 3: continued

\section{Steelcase Workplace B: Implement new technology and improve the balance sheet.}

The leaders at an international building products firm were on a mission to expand their overseas markets through the improved use of technology. Goals for the new workplace were simple but radical—reshape the workplace to align with a flatter, more horizontal organization and provide ready access to a global communications network. There was one catch. With an existing multi-million-dollar investment in systems furniture, it had to be accomplished with intelligent redesign and reuse.

In the new environment, multiple hoteling workspaces support mobile workers who carry computers instead of briefcases. Teleconferencing rooms connect workers from all over the globe. Every workspace, from lobby to private office, features plug-and-play capability and modem access.

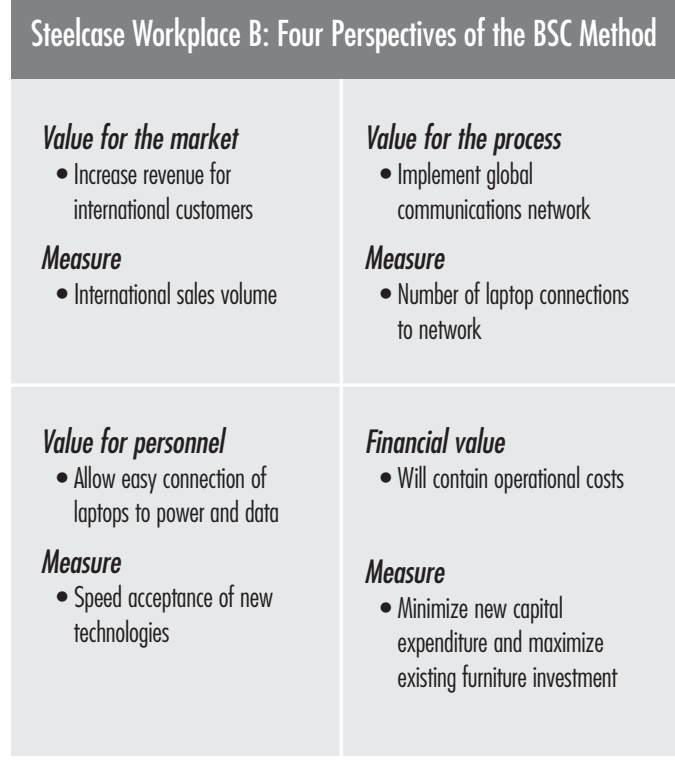

\section{Steelcase Workplace B: Four Perspectives of the BSC Method}

Value for the marke

- Increase revenue for

- Implement global

munications network

Measure

- Number of laptop connections to network

alue for personnel

- Allow easy connection of

laptops to power and data

(ceptance of new

- Minimize new capito expenditure and maximize xisting furniture investment

Continued from page 48

\section{Conclusion}

Design offers four powers or directions through which to create value in management, and these four directions can be seen as a system with the vision in the center. The design value model and its application through the Balanced Score Card toolkit provide a common language for designers and managers and this can help the design profession effect a change from project-based to knowledge-based.

Hence, this value model gives a conceptual framework to the emerging trend toward design leadership and explains the potential of design thinking for analyzing the challenges faced by managers (such as, sense building, complexity, user-oriented innovation, building a socially responsible organization, and so on). In this way, it facilitates the convergence of design and management.

\section{Acknowledgement}

Thanks to Giuseppe Attoma of Attoma Design and to Yo Kaminagai at RATP. Our warm thanks also go to Philippe Picaud and Philippe Vahé at Decathlon Design and to Catherine Gall and Thierry Coste at Steelcase Inc.

\section{Suggested Readings}

Borja de Mozota, B., Design Management (New

York and Paris: Allworth Press, 2002, 2003, 2006

(Turkish, Chinese, and Spanish translations).

Kaplan, R., and Norton, D., "Linking the Balanced Scorecard to Strategy," California Management Review, vol. 39 (1996), no. 1.

Reprint \#06172BOR44 